\title{
Feeding spectra of bivalve mollusks Unio and Dreissena from Kanevskoe Reservoir, Ukraine: are they food competitors or not?
}

\author{
Olesia N Makhutova ${ }^{*}$, Alexander A Protasov², Michail I Gladyshev ${ }^{1,3}$, Anzhelika A Sylaieva², \\ Nadezhda N Sushchik ${ }^{1,3}$, Irina A Morozovskaya ${ }^{2}$ and Galina S Kalachova ${ }^{1}$
}

\begin{abstract}
Background: One of the most abundant freshwater invaders is Dreissena polymorpha which provide wide-ranging direct and indirect impacts on the invaded ecosystems. A particularly notable impact on benthic communities is the extinction of native mollusks of the order Unionida. However, the settlement of D. polymorpha on unionid's shells in Kanevskoe Reservoir did not increase native unionid mortality. Since the reason for the successful coexistence of native unionids and invading dreissenids in Kanevskoe Reservoir is unknown, we hypothesized that these mollusks have different feeding spectra. To evaluate this hypothesis, we compared feeding spectra of the mollusks using a fatty acid (FA) marker analysis.
\end{abstract}

Results: Significant differences in the number and percentages of FAs were found among the mollusks and their food sources, seston, and sediments. Analyses of FA trophic markers in mollusk tissues showed that U. tumidus and Dreissena species mainly consumed algae (greens, diatoms, and dinoflagellates), cyanobacteria, and detritus particles enriched with bacteria. According to the multivariate statistical analysis, the mollusks had different feeding spectra: Dreissena species fed on planktonic sources, while U. tumidus mostly consumed food sources of benthic origin, mainly detritus. In addition, U. tumidus and Dreissena species differed in percentages of long-chain polyunsaturated FAs of n-3 and n-6 families and specific FAs which they could synthesize (20:1n-13 and 22:3 $\Delta 7,13,16)$.

Conclusions: $U$. tumidus and Dreissena species obviously obtained foods of different qualities. Dreissena consumed plankton species, i.e., more-valuable food, while U. tumidus fed on detritus and phytobenthic species which were of a lower food quality in terms of levels of physiologically important eicosapentaenoic and docosahexaenoic fatty acids. We concluded that the different feeding spectra of mollusks and adaptations of U. tumidus, the synthesis of specific FAs, might be the basis for the successful coexistence of native species and invaders for a long time.

Keywords: Invertebrates; Fatty acids; Ration; Invader

\section{Background}

Species introductions are now some of the most important human impacts on the world's ecosystems (Strayer et al. 2004). One of the most abundant freshwater invaders is the zebra mussel Dreissena polymorpha (Pallas 1771) which now has a broad geographic range in Europe and North America. Established populations of D. polymorpha can have wide-ranging direct and indirect impacts on

\footnotetext{
* Correspondence: makhutova@ibp.krasn.ru

${ }^{1}$ Institute of Biophysics of Siberian Branch of Russian Academy of Science, Akademgorodok, Krasnoyarsk 660036, Russia

Full list of author information is available at the end of the article
}

the invaded ecosystems (Sousa et al. 2011). Commonly observed changes include reductions in phytoplankton (Caraco et al. 1997; Strayer et al. 2008) and zooplankton (Pace et al. 1998; Strayer et al. 2008), increase water clarity (Caraco et al. 1997), changes in fish populations (Karatayev et al. 1997; Strayer et al. 2004), an increase of native bivalve mortality, and restructuring of benthic communities (Molloy et al. 1997; Burlakova et al. 2000; Karatayev et al. 2002).

A particularly notable impact on the benthos is the extinction of native mollusks of the order Unionida (Ricciardi et al. 1995; Jokela and Ricciardi 2008). Unionid mortality is strongly correlated to the Dreissena field density

\section{实}

(c) 2013 Makhutova et al.; licensee Springer. This is an Open Access article distributed under the terms of the Creative Commons Attribution License (http://creativecommons.org/licenses/by/2.0), which permits unrestricted use, distribution, and reproduction in any medium, provided the original work is properly cited. 
(Ricciardi et al. 1995). Invasions by dreissenids are thought to cause severe declines in unionids through physical disturbance and/or food competition (Thorp and Casper 2002). However, there are some examples where the negative effects were not so strong. For instance, the fouling of Unio by Dreissena species in Kievskoe Reservoir, Ukraine, did not cause mass unionid mortality (Kharchenko and Zorina-Sakharova 2002).

Unio tumidus (Philipsson 1788), D. polymorpha, and Dreissena bugensis (Andrusov 1897) inhabit Kanevskoe Reservoir (Dnieper River basin), Ukraine. D. bugensis there prefers soft benthic substrata and very rarely settles on Unio specimens, while D. polymorpha has actively settled on $U$. tumidus shells for many years. In contrast to most American and European lakes, the settlement of D. polymorpha on unionid's shells in Kanevskoe Reservoir did not increase native unionid mortality. Since the reason for the successful coexistence of native unionids and invading dreissenids in Kanevskoe Reservoir is unknown, we hypothesized that these mollusks have different feeding spectra. To evaluate this hypothesis, we compared feeding spectra of $U$. tumidus, D. polymorpha, and D. bugensis using a fatty acid (FA) marker analysis.

\section{Methods}

\section{Study site}

Samples were taken in the littoral zone of the upper part of Kanevskoe Reservoir (the Dnieper River, Ukraine) on 9 and 16 June 2010. The studied section of the reservoir is situated in a forest-steppe zone. The sampling site $\left(50^{\circ} 20^{\prime} \mathrm{N}, 30^{\circ} 36^{\prime} \mathrm{E}\right)$ was situated in the vicinity of $\mathrm{Kiev}$ City (Figure 1). The depth of the sampling site was around $2 \mathrm{~m}$. The bottom of the station was mainly silty sand. The temperature of the surface water on sampling days ranged $22.5^{\circ} \mathrm{C}$ to $24^{\circ} \mathrm{C}$. The main hydrological features of the reservoir are given elsewhere (Starodubtsev and Bogdanets 2012).

\section{Field sampling}

Samples were collected as follows. Equal volumes of water from the surface and at $1.3 \mathrm{~m}$ in depth were immediately pooled to form a pooled sample of phytoplankton. Then, $0.5 \mathrm{~L}$ from the pooled sample was preserved with Lugol's solution and kept in a dark place for 15 days in a cylindrical tube. After 15 days, a siphon draft tube was placed in the middle of the cylinder with sample, and $450 \mathrm{~mL}$ was carefully removed. Phytoplankton species from a sample of $50 \mathrm{~mL}$ in volume were identified and enumerated in a Nageotte chamber under a microscope (Olympus CX21, Shinjuku, Tokyo, Japan). Zooplankton samples were collected by pouring $50 \mathrm{~L}$ of surface water through a $75-\mu \mathrm{m}$ sieve. Retained materials were placed into individual vials and fixed with $4 \%$ formalin.
Zooplankton species were identified and enumerated in a Bogorov chamber under a stereomicroscope. Phytobenthic samples were randomly collected from the bottom at the sampling station. During collection, a diver opened a pre-vacuumed and closed plastic tube (with a diameter of $3 \mathrm{~cm}$ ) very close to the bottom surface. When opening the tube, fine deposited materials were gently aspirated into the tube from the substrata. Phytobenthic species were identified and enumerated in a Nageotte chamber under a microscope. Zoobenthic samples were collected from the bottom using a box-shaped sampler of $0.1 \times$ $0.1 \mathrm{~m}$. Zoobenthic organisms were withdrawn using appropriate forceps in the laboratory and placed into glass vials containing ethanol. Then, zoobenthic species were identified and enumerated under a stereomicroscope.

For the FA analysis, we sampled three bivalve mollusk species, $U$. tumidus $(n=3), D$. polymorpha $(n=8)$, and $D$. bugensis $(n=2)$, and their potential food sources of seston $(n=6)$ and sediments $(n=3)$. Each sample of mollusks consisted of the muscles of eight to ten randomly selected individuals. We collected Unio specimens which were fouled by $D$. polymorpha. D. polymorpha specimens were taken from various substrata, i.e., Unio shells, stones, and sediments, to encompass any possible environmental heterogeneity. D. bugensis was collected from sediments. Since it was impossible to thoroughly separate the guts from other parts of the mollusk body, the closing muscles, feet, and part of the mantle of several mollusks were pooled to obtain a sample for the FA analysis. Seston samples were collected from pooled samples of phytoplankton. Sediments were collected like the phytobenthic samples by gently aspirating fine deposited materials from the substrata into plastic tubes. Then, samples of seston and sediments were filtered onto membrane filters with pore size 0.75 to $0.85 \mu \mathrm{m}$ (Vladipor, Vladimir, Russia) and precovered with a layer of $\mathrm{BaSO}_{4}$ to facilitate the separation of residues. Filters were dried at $35^{\circ} \mathrm{C}$ for about $30 \mathrm{~min}$. Residues that were separated from the filter and tissue samples were placed into vials containing $2 \mathrm{~mL}$ of chloroform/methanol $(2: 1, v / v)$ and stored at $-20^{\circ} \mathrm{C}$ until further analysis. A visual control showed that $100 \%$ of the residue was recovered from the filters.

\section{FA analysis}

The methods of lipid extraction, transesterification (methylation) of the lipid extracts, and purification of methyl esters were described by Christie (2003). Briefly, lipids from the samples were extracted with chloroform/methanol $(2: 1, v / v)$ three times simultaneously with mechanical homogenization of the tissues with glass beads. Before extraction, a definite volume of an internal standard solution (a solution of free 19:0 in chloroform, $0.5 \mathrm{mg} / \mathrm{mL}$, Sigma-Aldrich, St. Louis, MO, USA) was added to the 


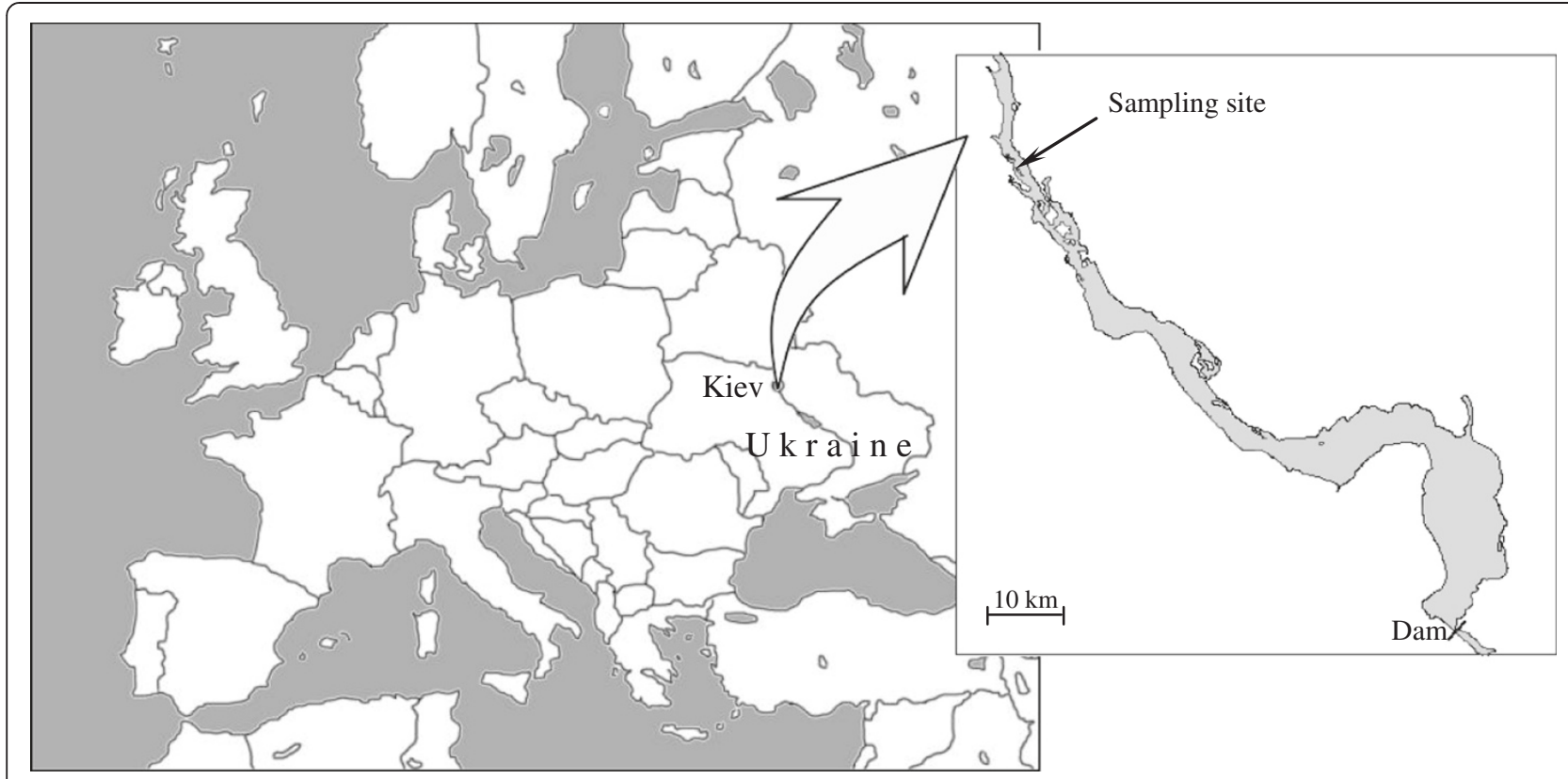

Figure 1 Map of sampling site.

samples. The volume of the internal standard solution that was added to the samples depended on the lipid content of the sample and corresponded to $1 \mathrm{~mL} / 1 \mathrm{~g}$ of wet weight of mollusk tissues, $20 \mu \mathrm{L} / 1 \mathrm{~L}$ of seston, and $100 \mu \mathrm{L} / 1 \mathrm{~L}$ of sediments. The combined lipid extracts were filtered, dried by passing through an anhydrous $\mathrm{Na}_{2} \mathrm{SO}_{4}$ layer, and evaporated at $35^{\circ} \mathrm{C}$. FA methyl esters (FAMEs) were prepared in a mixture of methanol/sulfuric acid (20: $1, v / v)$ at $90^{\circ} \mathrm{C}$ for $2 \mathrm{~h}$ as previously described (Makhutova et al. 2012). FAMEs were analyzed on a gas chromatograph equipped with a mass spectrometer detector (model 6890/5975C, Agilent Technologies, Santa Clara, CA, USA) and a 30-m-long $\times 0.25$-mm internal diameter HP-FFAP capillary column (Agilent Technologies, Santa Clara, CA, USA). The column temperature program was as follows: from $100^{\circ} \mathrm{C}$ to $190^{\circ} \mathrm{C}$ at $3^{\circ} \mathrm{C} / \mathrm{min}, 5 \mathrm{~min}$ isothermally, then to $230^{\circ} \mathrm{C}$ at $10^{\circ} \mathrm{C} / \mathrm{min}$, and $20 \mathrm{~min}$ isothermally. Other instrument conditions were as described elsewhere (Makhutova et al. 2012). FAME peaks were identified by their mass spectrum compared to those in a database (NIST-2005, Gaithersburg, MD, USA) and to those of available authentic standards (Sigma-Aldrich, St. Louis, MO, USA). Positions of double bonds in monoenoic acids were determined by gas chromatography (GC)-mass spectrometry (MS) of dimethyl disulfide adducts of FAs (Christie 2003). To determine the double bond positions in the polyenoic acids, including non-methylene-interrupted (NMI) FAs, GCMS of dimethyloxazoline derivatives of FAs was used (Carrido and Medina 2002). FAs that are usually used as biochemical markers of some particular taxonomic groups that occurred in the studied water body are shown in Table 1.

\section{Statistical analysis}

The mean, standard error (SE), Fisher's least significant difference (LSD) post hoc test, and a canonical correspondence analysis were carried out using STATISTICA software (vers. 9; StatSoft, Tulsa, OK, USA). A canonical correspondence analysis (CCA) was applied to the data matrix that included percentages of prominent FAs of mollusks, seston, and sediments (Table 2). Canonical analyses allow direct comparisons of two data matrices (Legendre and Legendre 2012). Since only 32 prominent acids from 94 identified acids were used in the CCA, the possible influence of $0 \%$ and low-percentage entries in the dataset was minimized.

\section{Results}

The biomass, abundance, and taxonomic composition of phytoplankton, zooplankton, phytobenthos, and zoobenthos on the sampling days are given in Tables 3 and 4. The content and composition of quantitatively prominent FAs of mollusks, seston, and sediments and FAs of high marker significance are shown in Table 2. In total, 94 FA compounds were identified in all samples.

Using the canonical correspondence analysis, mollusks, seston, and sediments were represented in a two-dimensional space according to the percentages (\% of total FAs) of prominent FAs (Figure 2). The first dimension explained $63.5 \%$ of the inertia (of the total Chi-square value) of the dataset, and the second dimension explained 


\begin{tabular}{|c|c|c|}
\hline Group & Fatty acid markers & References \\
\hline \multicolumn{3}{|l|}{ Phytoplankton group } \\
\hline \multirow[t]{3}{*}{ Chlorophyceae } & 18:2n-6, 18:3n-3, and C16 PUFAs n-3 and n-6 & Napolitano 1999 \\
\hline & & Viso and Marty 1993 \\
\hline & & Petkov and Garcia 2007 \\
\hline \multirow[t]{4}{*}{ Cryptophyceae } & Simultaneous occurrence of $18: 3 n-3$ and $18: 4 n-3 ;$ and $20: 5 n-3$ and $22: 6 n-3$ & Brett et al. 2009 \\
\hline & & Dijkman and Kromkamp 2006 \\
\hline & & Desvilettes et al. 1997 \\
\hline & & Guevara et al. 2011 \\
\hline \multirow[t]{2}{*}{ Dinophyceae } & $18: 4 n-3,18: 5 n-3$, and $22: 6 n-3$ & Napolitano 1999 \\
\hline & & Berge and Barnathan 2005 \\
\hline \multirow[t]{3}{*}{ Bacillariophyceae } & C16 PUFAs n-7, n-4, n-1, 20:5n-3, and 16:1n-7/16:0 > 1 & Dijkman and Kromkamp 2006 \\
\hline & & Shin et al. 2000 \\
\hline & & Prato et al. 2012 \\
\hline Cyanobacteria & $18: 3 n-3($ or $18: 3 n-6)$ & Gugger et al. 2002 \\
\hline \multirow[t]{2}{*}{ Heterotrophic bacteria } & Branched C15-17 SFAs and MUFAs, 18:1n-7, 16:1n-6, trans-16:1n-5, and 18:1n-8 & Napolitano 1999 \\
\hline & & Green and Scow 2000 \\
\hline Decomposed material & SFAs, especially $18: 0$ & Hama 1999 \\
\hline \multirow[t]{2}{*}{ Vascular plant detritus } & Long-chain SFAs (C20 to C32) & Shorland 1963 \\
\hline & & Napolitano 1999 \\
\hline \multirow[t]{2}{*}{ Copepoda } & C20 to C22 MUFAs & Hagen et al. 1993 \\
\hline & & Kattner et al. 2007 \\
\hline \multirow[t]{3}{*}{ Mollusca } & NMI FAs, 20:1n-13, and 22:2n-6 & Mezek et al. 2011 \\
\hline & & Zhukova 2007 \\
\hline & & Saito and Hashimoto 2010 \\
\hline
\end{tabular}

SFAs, saturated fatty acids; MUFAs, monounsaturated fatty acids; PUFAs, polyunsaturated fatty acids; NMI FAs, non-methylene-interrupted fatty acids.

16.6\%. Chi-square values for both dimensions and the total Chi-square value were significant $(p=0.00002)$. The first dimension (Figure 2) demonstrated large differences between seston and sediments on one hand, and mollusks on the other. The positioning of samples in the first dimension was mostly provided by differences in their percentages of markers of phytoplankton (C16 polyunsaturated FAs; PUFAs) and markers of vascular plant detritus (C24 to C26 saturated fatty acids; SFAs) that were abundant in seston and sediments on the one hand, and long-chain n-3 and n-6 PUFAs that were abundant in animals, on the other hand (Figure 2, Table 2). The second dimension, although comparatively less substantial, was also significant and indicated differences between Unio and Dreissena (Figure 2). Differences between mollusks were primarily provided by percentages of 22:4n-6, 20:4n-6, and NMI 22:3 $\Delta 7,13,16$ that were high in Unio and percentages of $18: 1 n-7$ and $22: 6 n-3$ that were high in Dreissena species (Figure 2, Table 2). Seston and sediments also tended to differ in the second dimension (Figure 2). This difference was provided by the percentage of a marker of decomposed material (18:0) that was abundant in sediments and by percentages of markers of phytoplankton (18:2n-6 and 18:3n-3) and bacteria (i15:0) that were abundant in seston (Figure 2, Table 2).

Differences between the percentages of FAs in mollusks and their food items were specified by Fisher's LSD post hoc test. Mollusks had significantly higher percentages of taxon-specific markers (20:1n-13, 22:2n-6, and NMI FAs), animal FAs, and long-chain n-3 and n-6 PUFAs compared to seston and sediments (Table 2). In turn, percentages of FA markers of phytoplankton (16:1n-7, 16:1n-9, and C16 PUFAs), zooplankton (22:1n-9), and vascular plant detritus (C24 to C26 SFAs) in seston and sediments were significantly higher than those in mollusks (Table 2). The compositions of bacterial FAs in mollusks were nearly the same as those in seston and sediments (Table 2).

Concerning the FA composition of food sources, seston had significantly higher percentages of markers of phytoplankton (C16 and C18 PUFAs), some bacterial markers (i15:0 and 18:1n-7), and physiologically important PUFAs, 
Table 2 Average values of prominent fatty acids and content of FAs in total lipids of mollusks

\begin{tabular}{|c|c|c|c|c|c|c|c|c|c|c|c|c|c|c|c|}
\hline \multirow{2}{*}{$\frac{\text { FAs }}{14: 0}$} & \multicolumn{3}{|c|}{ Seston } & \multicolumn{3}{|c|}{ Sediments } & \multicolumn{3}{|c|}{ U. tumidus } & \multicolumn{3}{|c|}{ D. polymorpha } & \multicolumn{3}{|c|}{ D. bugensis } \\
\hline & 5.4 & \pm & $0.3^{\mathrm{a}}$ & 5.4 & \pm & $1.2^{\mathrm{a}}$ & 1.0 & \pm & $0.0^{\mathrm{b}}$ & 1.7 & \pm & $0.3^{b}$ & 2.1 & \pm & $0.3^{\mathrm{b}}$ \\
\hline $15: 0$ & 1.1 & \pm & $0.1^{\mathrm{ab}}$ & 1.4 & \pm & $0.4^{\mathrm{a}}$ & 1.2 & \pm & $0.0^{\mathrm{ac}}$ & 0.8 & \pm & $0.1^{b c}$ & 0.7 & \pm & $0.1^{b c}$ \\
\hline $16: 0$ & 23.8 & \pm & $2.1^{\mathrm{a}}$ & 30.3 & \pm & $1.0^{\mathrm{b}}$ & 16.6 & \pm & $0.2^{c}$ & 23.9 & \pm & $1.2^{\mathrm{a}}$ & 23.1 & \pm & $2.0^{a c}$ \\
\hline $17: 0$ & 0.7 & \pm & $0.1^{a}$ & 0.8 & \pm & $0.2^{\mathrm{a}}$ & 2.9 & \pm & $0.0^{\mathrm{b}}$ & 1.4 & \pm & $0.1^{c}$ & 1.0 & \pm & $0.1^{\mathrm{ac}}$ \\
\hline $18: 0$ & 15.0 & \pm & $3.2^{\mathrm{a}}$ & 23.5 & \pm & $4.7^{\mathrm{b}}$ & 9.1 & \pm & $0.3^{\mathrm{ac}}$ & 5.6 & \pm & $0.2^{c}$ & 4.5 & \pm & $0.3^{c}$ \\
\hline $20: 0$ & 1.0 & \pm & $0.1^{\mathrm{a}}$ & 1.2 & \pm & $0.1^{\mathrm{a}}$ & 0.2 & \pm & $0.1^{b}$ & 0.4 & \pm & $0.1^{\mathrm{b}}$ & 0.7 & \pm & $0.0^{\mathrm{ab}}$ \\
\hline $22: 0$ & 1.3 & \pm & $0.2^{\mathrm{a}}$ & 1.7 & \pm & $0.5^{\mathrm{a}}$ & 0.3 & \pm & $0.1^{b}$ & 0.3 & \pm & $0.1^{\mathrm{b}}$ & 0.2 & \pm & $0.0^{\mathrm{b}}$ \\
\hline $24: 0$ & 1.3 & \pm & $0.2^{\mathrm{a}}$ & 1.7 & \pm & $0.1^{\mathrm{a}}$ & 0.1 & \pm & $0.1^{b}$ & 0.2 & \pm & $0.1^{\mathrm{b}}$ & 0.1 & \pm & $0.0^{b}$ \\
\hline $26: 0$ & 0.6 & \pm & $0.1^{\mathrm{a}}$ & 0.6 & \pm & $0.1^{\mathrm{a}}$ & 0.0 & \pm & $0.0^{\mathrm{b}}$ & 0.0 & \pm & $0.0^{b}$ & 0.0 & \pm & $0.0^{\mathrm{b}}$ \\
\hline ¡15:0 & 1.2 & \pm & $0.2^{\mathrm{a}}$ & 0.7 & \pm & $0.2^{b}$ & 0.1 & \pm & $0.0^{c}$ & 0.2 & \pm & $0.0^{c}$ & 0.2 & \pm & $0.0^{b c}$ \\
\hline i17:0 & 0.6 & \pm & $0.1^{\mathrm{ac}}$ & 0.4 & \pm & $0.1^{\mathrm{a}}$ & 1.1 & \pm & $0.1^{b}$ & 0.7 & \pm & $0.1^{c}$ & 0.7 & \pm & $0.1^{\mathrm{ac}}$ \\
\hline $16: 1(n-7+n-9)$ & 10.1 & \pm & $0.9^{a}$ & 6.9 & \pm & $1.6^{\mathrm{b}}$ & 3.4 & \pm & $0.2^{c}$ & 4.6 & \pm & $0.5^{b c}$ & 6.4 & \pm & $0.0^{b c}$ \\
\hline $18: 1 n-9$ & 5.2 & \pm & $0.7^{\mathrm{ab}}$ & 5.4 & \pm & $0.6^{\mathrm{ab}}$ & 5.9 & \pm & $0.3^{\mathrm{a}}$ & 4.0 & \pm & $0.3^{b}$ & 4.4 & \pm & $0.1^{\mathrm{ab}}$ \\
\hline $18: 1 n-7$ & 2.6 & \pm & $0.5^{\mathrm{a}}$ & 1.0 & \pm & $0.2^{b}$ & 1.0 & \pm & $0.1^{b}$ & 2.9 & \pm & $0.1^{\mathrm{a}}$ & 3.8 & \pm & $0.2^{\mathrm{a}}$ \\
\hline $20: 1 n-13$ & 0.0 & \pm & $0.0^{\mathrm{a}}$ & 0.0 & \pm & $0.0^{\mathrm{a}}$ & 13.6 & \pm & $0.5^{\mathrm{b}}$ & 7.8 & \pm & $0.6^{c}$ & 6.4 & \pm & $0.3^{c}$ \\
\hline $20: 1 n-9$ & 0.5 & \pm & $0.1^{a}$ & 0.4 & \pm & $0.0^{\mathrm{a}}$ & 1.3 & \pm & $0.0^{\mathrm{b}}$ & 2.7 & \pm & $0.2^{c}$ & 1.9 & \pm & $0.0^{d}$ \\
\hline $22: 1 n-9$ & 2.3 & \pm & $0.6^{a}$ & 3.1 & \pm & $0.1^{\mathrm{a}}$ & 0.3 & \pm & $0.0^{\mathrm{b}}$ & 0.3 & \pm & $0.1^{\mathrm{b}}$ & 0.2 & \pm & $0.1^{b}$ \\
\hline $22: 1 n-7$ & 0.1 & \pm & $0.0^{\mathrm{a}}$ & 0.0 & \pm & $0.0^{\mathrm{a}}$ & 0.4 & \pm & $0.0^{\mathrm{b}}$ & 0.5 & \pm & $0.1^{\mathrm{b}}$ & 0.4 & \pm & $0.1^{b}$ \\
\hline $16: 2 n-4$ & 1.4 & \pm & $0.2^{a}$ & 0.8 & \pm & $0.2^{b}$ & 0.0 & \pm & $0.0^{c}$ & 0.1 & \pm & $0.0^{c}$ & 0.1 & \pm & $0.0^{c}$ \\
\hline $16: 3 n-4$ & 1.6 & \pm & $0.2^{a}$ & 1.0 & \pm & $0.2^{b}$ & 0.0 & \pm & $0.0^{c}$ & 0.0 & \pm & $0.0^{c}$ & 0.0 & \pm & $0.0^{c}$ \\
\hline $16: 4 n-3$ & 1.1 & \pm & $0.2^{\mathrm{a}}$ & 1.0 & \pm & $0.3^{\mathrm{a}}$ & 0.0 & \pm & $0.0^{\mathrm{b}}$ & 0.0 & \pm & $0.0^{\mathrm{b}}$ & 0.1 & \pm & $0.0^{\mathrm{b}}$ \\
\hline $18: 2 n-6$ & 2.1 & \pm & $0.2^{\mathrm{a}}$ & 1.4 & \pm & $0.1^{b}$ & 3.4 & \pm & $0.1^{c}$ & 1.5 & \pm & $0.1^{\mathrm{b}}$ & 2.0 & \pm & $0.1^{a b}$ \\
\hline $18: 3 n-3$ & 3.3 & \pm & $0.5^{\mathrm{a}}$ & 1.7 & \pm & $0.3^{b}$ & 1.1 & \pm & $0.0^{\mathrm{b}}$ & 1.9 & \pm & $0.1^{b}$ & 5.3 & \pm & $0.1^{c}$ \\
\hline $18: 4 n-3$ & 2.2 & \pm & $0.3^{\mathrm{a}}$ & 2.0 & \pm & $0.4^{\mathrm{a}}$ & 0.3 & \pm & $0.0^{\mathrm{b}}$ & 0.9 & \pm & $0.1^{b}$ & 3.0 & \pm & $0.1^{c}$ \\
\hline $20: 4 n-6$ & 0.7 & \pm & $0.2^{\mathrm{a}}$ & 0.3 & \pm & $0.0^{\mathrm{a}}$ & 8.7 & \pm & $0.4^{b}$ & 3.6 & \pm & $0.3^{c}$ & 2.2 & \pm & $0.4^{d}$ \\
\hline $20: 5 n-3$ & 5.1 & \pm & $0.7^{\mathrm{a}}$ & 2.4 & \pm & $0.2^{\mathrm{b}}$ & 4.3 & \pm & $0.3^{\mathrm{ab}}$ & 6.4 & \pm & $0.3^{c}$ & 7.7 & \pm & $0.7^{c}$ \\
\hline $22: 2 n-6$ & 0.0 & \pm & $0.0^{\mathrm{a}}$ & 0.0 & \pm & $0.0^{\mathrm{a}}$ & 3.3 & \pm & $0.4^{b}$ & 2.9 & \pm & $0.2^{b}$ & 2.7 & \pm & $0.1^{\mathrm{b}}$ \\
\hline $22: 3 \Delta 7,13,16$ & 0.0 & \pm & $0.0^{\mathrm{a}}$ & 0.0 & \pm & $0.0^{\mathrm{a}}$ & 2.0 & \pm & $0.3^{\mathrm{b}}$ & 0.8 & \pm & $0.1^{c}$ & 0.8 & \pm & $0.2^{c}$ \\
\hline $22: 4 n-6$ & 0.0 & \pm & $0.0^{\mathrm{a}}$ & 0.0 & \pm & $0.0^{\mathrm{a}}$ & 2.9 & \pm & $0.1^{b}$ & 0.5 & \pm & $0.0^{c}$ & 0.3 & \pm & $0.0^{d}$ \\
\hline $22: 5 n-6$ & 0.7 & \pm & $0.1^{a}$ & 0.0 & \pm & $0.0^{\mathrm{b}}$ & 1.6 & \pm & $0.2^{c}$ & 3.3 & \pm & $0.2^{d}$ & 1.8 & \pm & $0.1^{c}$ \\
\hline $22: 5 n-3$ & 0.2 & \pm & $0.0^{\mathrm{a}}$ & 0.0 & \pm & $0.0^{\mathrm{a}}$ & 4.9 & \pm & $0.1^{b}$ & 5.1 & \pm & $0.2^{b}$ & 3.9 & \pm & $0.2^{c}$ \\
\hline $22: 6 n-3$ & 1.5 & \pm & $0.3^{\mathrm{a}}$ & 0.0 & \pm & $0.0^{\mathrm{b}}$ & 1.6 & \pm & $0.1^{\mathrm{a}}$ & 8.0 & \pm & $0.4^{c}$ & 5.1 & \pm & $0.4^{d}$ \\
\hline BFAs & 7.8 & \pm & $1.2^{\mathrm{a}}$ & 5.4 & \pm & $1.5^{\mathrm{a}}$ & 6.5 & \pm & $0.1^{\mathrm{a}}$ & 6.3 & \pm & $0.2^{\mathrm{a}}$ & 6.7 & \pm & $0.3^{\mathrm{a}}$ \\
\hline FAs, total & & nd & & & nd & & 3.5 & \pm & $0.4^{\mathrm{ab}}$ & 3.0 & \pm & $0.1^{\mathrm{a}}$ & 4.0 & \pm & $0.3^{b}$ \\
\hline
\end{tabular}

Average values of quantitatively prominent fatty acids (FAs; \% of the total, \pm SE) of seston ( $n=6)$, sediments $(n=3)$, Unio tumidus ( $n=3)$, Dreissena polymorpha $(n=8)$, and $D$. bugensis $(n=2)$, and the content of FAs in total lipids (mg/g wet weight, \pm SE) of mollusks from Kanevskoe Reservoir, Ukraine. Means in a row labeled with the same superscript letter do not significantly differ at $p<0.05$ according to Fisher's LSD post hoc test. BFAs, FA markers of bacteria (the sum of $\mathrm{i}$, ai 14:0; i, ai15:0; ai15:1; 15:0; i16:0; i17:0; 17:0; and 18:1n-7); nd, not determined.

namely eicosapentaenoic acid (20:5n-3, EPA) and docosahexaenoic acid (22:6n-3, DHA), than sediments (Table 2).

Different species of mollusks differed from each other in percentages of some FAs. Dreissena species had higher percentages of FA markers associated with seston, while Unio had a higher percentage of stearic acid (18:0), which was abundant in sediments (Table 2). In addition, Unio had significantly higher percentages of markers of mollusks (Table 1) and n-6 PUFAs and lower percentages of n-3 PUFAs and the bacterial 18:1n-7, than Dreissena species (Table 2). D. polymorpha differed from $D$. bugensis mostly by higher percentages of C20-22 PUFAs and lower percentages of C18 PUFAs (Table 2). 
Table 3 Abundance, biomass, and taxonomic composition of phytoplankton and phytobenthos from Kanevskoe Reservoir, Ukraine

\begin{tabular}{|c|c|c|c|c|c|c|c|c|}
\hline & Date & Number & $\begin{array}{l}\text { Total abundance } \\
\left(10^{3} \text { cells/L) }\right.\end{array}$ & $\begin{array}{l}\text { Total biomass } \\
(\mathrm{mg} / \mathrm{L})\end{array}$ & Order & $\begin{array}{c}\text { Percent total } \\
\text { abundance }\end{array}$ & $\begin{array}{l}\text { Percent total } \\
\text { biomass }\end{array}$ & $\begin{array}{c}\text { Dominant } \\
\text { species }\end{array}$ \\
\hline \multirow[t]{9}{*}{ Phytoplankton } & 9 June 2010 & 7 & 780 & 0.407 & Dinophyta & 2.3 & 72.3 & Gymnodinium sp. \\
\hline & & & & & Bacillariophyta & 16.7 & 24.5 & \\
\hline & & & & & Chlorophyta & 81.0 & 3.2 & \\
\hline & 16 June 2010 & 12 & 10,560 & 6.68 & Bacillariophyta & 42.2 & 56.8 & Aulocoseira granulata \\
\hline & & & & & Dinophyta & 2.3 & 20.2 & Gymnodinium sp. \\
\hline & & & & & Cyanophyta & 28.9 & 16.9 & \\
\hline & & & & & Euglenophyta & 0.8 & 4.4 & \\
\hline & & & & & Chlorophyta & 25.8 & 1.7 & \\
\hline & & & $\begin{array}{l}\text { Total abundance } \\
\left(10^{3} \text { cells } / \mathrm{m}^{2}\right)\end{array}$ & $\begin{array}{l}\text { Total biomass } \\
\left(\mathrm{g} / \mathrm{m}^{2}\right)\end{array}$ & & & & \\
\hline \multirow[t]{7}{*}{ Phytobenthos } & 09 June 2010 & 33 & $1,328,238$ & 2.251 & Bacillariophyta & 79.8 & 90.9 & Aulocoseira granulate \\
\hline & & & & & Chlorophyta & 16.2 & 5.4 & Aulocoseira ambigua \\
\hline & & & & & Euglenophyta & 1.6 & 3.6 & Amphora ovalis \\
\hline & & & & & Cyanophyta & 2.4 & 0.06 & \\
\hline & 16 June 2010 & 19 & $1,341,985$ & 0.734 & Bacillariophyta & 27.4 & 85.7 & Aulocoseira granulata \\
\hline & & & & & Chlorophyta & 28.1 & 14.3 & \\
\hline & & & & & Cyanophyta & 44.5 & 0.04 & \\
\hline
\end{tabular}

\section{Discussion}

The FA compositions of bivalve mollusk species significantly differed from those of their potential food sources of seston and sediments. Many authors revealed that FA compositions of animals do not completely reflect the FA compositions of the foods consumed. Along with trophic factors, phylogenetic factors are important determinants of FA profiles in aquatic invertebrates (Kraffe et al. 2008; Makhutova et al. 2011; Lau et al. 2012). Some invertebrates possess active elongases and desaturases and can significantly modify dietary FAs (Bell and Tocher 2009; Kelly and Scheibling 2012). Essential

Table 4 Abundance, biomass, and taxonomic composition of zooplankton and zoobenthos from Kanevskoe Reservoir, Ukraine

\begin{tabular}{|c|c|c|c|c|c|c|}
\hline & Date & Number & $\begin{array}{l}\text { Total abundance } \\
\text { (individuals/L) }\end{array}$ & $\begin{array}{l}\text { Total biomass } \\
\text { (mg/L) }\end{array}$ & Dominant species & Percent total biomass \\
\hline \multirow[t]{3}{*}{ Zooplankton } & 9 June 2010 & 32 & 56.270 & 0.496 & Dreissena, Veliger & 42.6 \\
\hline & & & & & Cyclopoida juv., Copepoda & 30.7 \\
\hline & & & $\begin{array}{l}\text { Total abundance } \\
\text { (individuals } / \mathrm{m}^{2} \text { ) }\end{array}$ & $\begin{array}{l}\text { Total biomass } \\
\left(\mathrm{g} / \mathrm{m}^{2}\right)\end{array}$ & & \\
\hline Zoobenthos & 16 June 2010 & & & & & \\
\hline \multirow[t]{3}{*}{ Unionidae } & & 3 & 21.7 & 972.4 & Unio tumidus & 17.8 \\
\hline & & & & & Unio pictorum & 16.4 \\
\hline & & & & & Anodonta anatina & 16.6 \\
\hline \multirow[t]{2}{*}{ Dreissenidae } & & 2 & 1147.3 & 517.76 & Dreissena polymorpha & 37.1 \\
\hline & & & & & Dreissena bugensis & 0.2 \\
\hline \multirow[t]{6}{*}{ Others } & & 27 & 596.3 & 165.72 & Viviparus viviparous & \\
\hline & & & & & Bithynia tentaculata & $95.09^{a}$ \\
\hline & & & & & Theodoxus fluviatilis & $2.37^{\mathrm{a}}$ \\
\hline & & & & & Lithoglyphus naticoides & $1.14^{\mathrm{a}}$ \\
\hline & & & & & Dikerogammarus & $0.58^{\mathrm{a}}$ \\
\hline & & & & & Haemobaphes & $0.44^{\mathrm{a}}$ \\
\hline
\end{tabular}

aPercent biomass of 'Others.' 


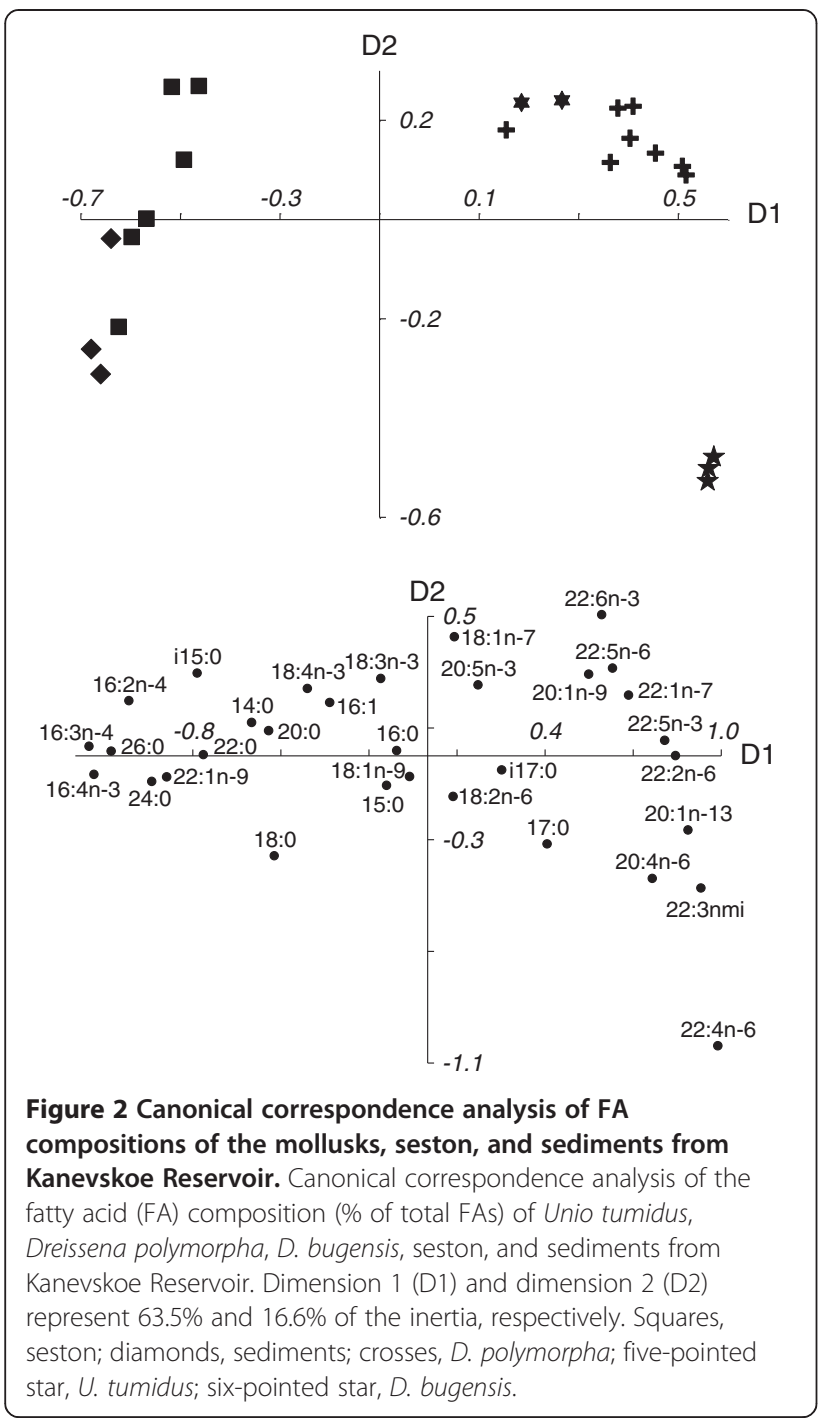

dietary FAs, such as $18: 2 n-6$ and $18: 3 n-3$, can be used to synthesize physiologically important EPA and DHA that leads to decreased proportions of C18 PUFAs and increased proportions of C20 and C22 PUFAs in animal tissues compared to food items (Castell et al. 2004; De Troch et al. 2012). Long-chain PUFAs, such as EPA and DHA, are considered physiologically crucial and likely conservatively retained in tissues compared to other compounds (Gladyshev et al. 2011; Kelly and Scheibling 2012). In contrast, some other FAs, including FA markers of algae, are used as energetic resources and are catabolized in animal tissues (Brett et al. 2006; Gladyshev et al. 2011).

Seston and sediments also differed in percentages of several FA markers, showing higher input of decomposed material in sediments and a significant part of active phytoplankton, zooplankton, and bacterioplankton in seston. Although dominating taxa of the phytoplankton and phytobenthos were diatoms and dinoflagellates, FA markers of these algae were not abundant in seston and especially in sediments. The relatively low proportion of algal biomass in the seston is a possible reason for this result. High percentages of SFAs (18:0 and 20:0 to 26:0) and bacterial FAs in sediments and seston indicated a high proportion of detrital particles that may have comprised vascular plant detritus and also pseudofeces, feces, and other excreta of mollusks. Thus, in general, the contributions of algae to seston and especially to sediments were not high.

Differences in FA percentages of Unio and Dreissena species are apparently associated with differences in food sources of the mollusks. Dreissena likely preferred plankton species, while Unio probably consumed more detritus and benthic species. In addition to the high percentage of the detritus marker and relatively low levels of algae markers in Unio, NMI FAs may also indicate the preferred consumption of detritus by Unio. It is known that the unusual unsaturated pattern of NMI FAs confers a higher resistance to oxidative processes and microbial lipases on cell membranes than do common PUFAs (Irazù et al. 1984; Barnathan 2009). Thus, a high level of NMI FAs is considered a biochemical adaptation of benthic animals to their specific habitats (Barnathan 2009). In addition, some authors related NMI FA biosynthesis in mollusks to deficiencies in the physiologically important n-3 PUFAs, EPA, and DHA (Pirini et al. 2007). Both the sediments studied and Unio tissues were poor in EPA and DHA, and Unio feeding on benthic species may synthesize NMI FAs to compensate for the PUFA dietary deficiency.

As reported in the literature, bacteria can be a significant source of organic carbon and nitrogen for some bivalve mollusks (Nichols and Garling 2000). Unio and Dreissena studied in the present paper apparently consumed bacteria. It is well known that bacteria taxa markedly differ in FA markers or ratios (Bertone et al. 1996; Napolitano 1999; Saliot et al. 2001). When Unio was compared to both Dreissena species, it had significantly higher percentages of bacterial i17:0 and 17:0, which are likely markers of sulfate-reducing bacteria (Napolitano 1999). Hence, Unio might consume these bacteria together with detritus from sediments. In turn, percentages of another bacterial acid, 18:1n-7, which is abundant in cyanobacteria, and sulfur-oxidizing and aerobic bacteria (Napolitano 1999), were particularly high in both Dreissena species and seston samples. It is likely that Dreissena mostly consumed planktonic bacterial species.

Percentages of FA markers of green algae and cyanobacteria in mollusks and their food items were not high, due to the low biomass of Cyanophyta and Chlorophyta in the phytoplankton and phytobenthos. However, all of the mollusks studied probably consumed these algae. The percentage of 18:2n-6, the essential acid synthesized 
by algae (Gugger et al. 2002; Caramujo et al. 2008), was higher in Unio than in either Dreissena species. Apparently, Unio consumed some algal species which contained this acid or selectively accumulated 18:2n-6 from its food. These data confirmed the selective feeding by bivalve mollusks as was reported by many authors (Dionisio Pires et al. 2004; Naddafi et al. 2007; Vuorio et al. 2007). Percentages of the essential FAs, $18: 3 n-3$ and 18:4n-3, were substantially higher in D. bugensis, than in Unio and D. polymorpha. In aquatic food webs, the former FA is synthesized by green algae, cyanobacteria, or macrophytes, while the latter is abundant in some algal taxa, such as dinoflagellates and cryptophytes (Desvilettes et al. 1997; Gugger et al. 2002; Caramujo et al. 2008). D. bugensis may accumulate them from algal food sources that are rich in 18:3n-3 and 18:4n-3, or selectively assimilates them in contrast to other FAs. The source of 18:4n-3 could have been dinoflagellates that were the dominant species of phytoplankton (Table 3). DHA, another marker of dinoflagellates, was found in seston and was also significant in D. bugensis. Alternatively, D. bugensis might not use C18 n-3 PUFAs for subsequent FA biosynthesis as effectively as $D$. polymorpha. Significantly lower percentages of long-chain PUFAs in D. bugensis compared to D. polymorpha possibly confirm this suggestion.

Bacillariophyta are one of the dominating groups among the phytoplankton and phytobenthos (Table 3). However, we detected only negligible amounts of C16 PUFAs of the $\mathrm{n}-1, \mathrm{n}-4$, and $\mathrm{n}-7$ families, markers of diatoms, in the mollusks studied. It was shown that consumers store these FAs mainly as triacylglycerols (TAGs) and preferentially use them for catabolism (Gladyshev et al. 2011). The mollusk tissues studied were poor in TAGs (our unpublished data), and hence, we cannot estimate the consumption of diatoms by mollusks using C16 PUFA markers. In addition to the above-mentioned C16 PUFAs, EPA and 16:1n-7 are also considered markers of diatoms (Table 1). Dreissena species had significant amounts of 20:5n-3 and 16:1 (mostly 16:1n-7), compared to Unio. Thus, we presumed that the consumption of diatoms by Dreissena species was higher than by Unio.

FA markers of vascular plant detritus may also be preferentially stored as TAGs. They were abundant in the seston and sediments, but insignificant in mollusks.

Zooplankton can also be a potential food source for mollusks. Copepods and veligers of Dreissena are dominant zooplankton species in the reservoir studied (Table 4), and their sizes were $>0.2 \mathrm{~mm}$. Particles of this size are too big and likely inedible by the studied species, especially Dreissena. Rotifers are of a suitable size, but their abundance and biomass were low. The high percentage of 22:1n-9, an FA marker of copepods (Table 1), in the seston and sediments, and low percentage of this acid in mollusks also indicated that mollusks did not feed on copepods. However, we did not take into account heterotrophic flagellates and ciliates as potential food items, which might be the sources of 18:2n-6, 20:4n-6, and 22:6n-3.

Thus, according to the FA marker analyses, Dreissena species and Unio had the following differences in feeding spectra. Dreissena preferred planktonic algae and bacteria, while Unio mostly consumed detritus and phytobenthic species. These results are in agreement with those of Cole and Solomon (2012) that D. polymorpha preferred phytoplankton compared to other food items. Furthermore, our results confirm the findings of Nichols and Garling (2000) that the main food source of unionids is detritus enriched with bacteria.

In addition to selective feeding, other factors could have caused differences in the feeding spectra of Unio and Dreissena. Dreissena, which settled on Unio shells, had a higher location compare to the fouled Unio. Hence, there was a higher availability of sestonic food items for Dreissena, while there was a higher availability of food items from sediments for Unio. Possible differences in particle sizes consumed by mollusks also might affect rations of mollusk species. As is known, dreissenids and unionids filter particles of a broad size range, including colonial and filamentous algae (Dionisio Pires et al. 2004; Bontes et al. 2007; Vanderploeg et al. 2009). The preferred sizes for Dreissena and Unio were similar and varied by up to $250 \mu \mathrm{m}$ (Nichols and Garling 2000; Christian et al. 2004; Vaughn et al. 2008). This range includes sizes of almost all algal and bacterial species in the reservoir studied. Thus, all mollusks inhabiting Kanevskoe Reservoir ingested particles of the same range; consequently, the size of food particles was unlikely the reason for differences in the feeding spectra of these mollusks.

Unio and Dreissena species probably had significant differences in FA biosynthesis, since their percentages of n-6 and n-3 PUFAs, NMI FAs, and 20:1n-13 significantly differed. High percentages of n-3 PUFAs, especially EPA and DHA, in Dreissena species compared to Unio and food items probably indicate selective feeding and/or synthesis of these PUFAs by dreissenids from the essential precursors, C18 PUFAs. By contrast, Unio had significantly higher percentages of long-chain n-6 PUFAs, especially 20:4n-6 and 22:4n-6. These acids can be synthesized by Unio from dietary $18: 2 n-6$ by $\Delta 6$ and $\Delta 5$ desaturases, which were detected in animals (Berge and Barnathan 2005; Kelly and Scheibling 2012). The mollusks studied, especially Unio, had a high level of 20:1n-13. Mollusks of different taxonomic positions and feeding spectra are known to contain a significant amount of this unusual isomer of 20:1 (e.g., Kawashima and Ohnishi 2004; Zhukova 2007; Saito and Hashimoto 2010; Kharlamenko et al. 2011). The method of biosynthesis of this FA is unclear. Some authors considered that $20: 1 \mathrm{n}-13$ is synthesized from $18: 1 \mathrm{n}-13$ by 
C-2 elongation, whereas $18: 1 \mathrm{n}-13$ is derived from $18: 0$ by the action of $\Delta 5$ desaturase, generally common in bivalves (Saito and Osako 2007). However, some authors supposed that $20: 1 \mathrm{n}-13$ might be formed by a chain-shortening of 22:1n-13 which is itself formed by $\Delta 9$ desaturase acting on the 22:0 FA (Mansour et al. 2005). The role of 20:1n-13 in animals is unclear.

\section{Conclusions}

Our study demonstrated divergence in the feeding spectra of these mollusks (native populations of $U$. tumidus and invading populations of Dreissena species), which cohabitated and formed common druses. They obviously obtained foods of different qualities. Dreissena consumed plankton species, i.e., more-valuable food, while Unio fed on detritus and phytobenthic species which were of a lower food quality in terms of levels of physiologically important EPA and DHA. Under a deficiency of essential PUFAs, Unio synthesized specific FAs to compensate for the low food quality. We concluded that the different feeding spectra of mollusks and specific adaptations of Unio might be the basis for the successful coexistence of native species and invaders for a long time.

\section{Competing interests}

The authors declare that they have no competing interests.

\section{Authors' contributions}

AAP, ONM, MIG, and NNS conceived and designed the study. AAP, AAS, and IAM participated in the field trips for sampling and carried out hydrobiological analyses. ONM and GSK carried out biochemical analyses. MIG carried out statistical analyses and made the figures. ONM wrote the manuscript. MIG and NNS made intellectual contributions and reviewed the manuscript. All authors read and approved the final manuscript.

\section{Acknowledgements}

This work was supported by a grant (N 41/028) from The State Fund for Fundamental Researches of Ukraine, and by project B-15 of Siberian Federal Univ., carried out according to Federal Tasks of the Ministry of Education and Science of the Russian Federation, Moscow, Russia.

\section{Author details \\ ${ }^{1}$ Institute of Biophysics of Siberian Branch of Russian Academy of Science, Akademgorodok, Krasnoyarsk 660036, Russia. ${ }^{2}$ Institute of Hydrobiology, National Academy of Sciences of Ukraine, pr. Geroyev Stalingrada 12, Kiev 04210, Ukraine. ${ }^{3}$ Siberian Federal University, Svobodny av. 79, Krasnoyarsk 660041, Russia.}

Received: 11 April 2013 Accepted: 22 October 2013 Published: 12 December 2013

\section{References}

Barnathan G (2009) Non-methylene-interrupted fatty acids from marine invertebrates: occurrence, characterization and biological properties. Biochimie 91:671-678

Bell MV, Tocher DR (2009) Biosynthesis of polyunsaturated fatty acids in aquatic ecosystems: general pathways and new directions. In: Arts MT, Kainz MJ, Brett MT (ed) Lipids in aquatic ecosystems. Springer, New York, pp 211-236

Berge JP, Barnathan G (2005) Fatty acids from lipids of marine organisms: molecular biodiversity, roles as biomarkers, biologically active compounds, and economical aspects. In: Gal YL, Ulber R (ed) Marine biotechnology I, 96th edition. Springer-Verlag, Berlin, Heldelberg, pp 49-125

Bertone S, Glacomini M, Ruggiero C, Piccarolo C, Calegari L (1996) Automated systems for identification of heterotrophic marine bacteria on the basis of their fatty acid composition. Appl Environ Microbiol 62:2122-2132
Bontes BM, Verschoor AM, Dionisio Pires LM, Van Donk E, lbelings BW (2007) Functional response of Anodonta anatina feeding on a green alga and four strains of cyanobacteria, differing in shape, size and toxicity. Hydrobiology 584:191-204

Brett MT, Muller-Navarra DC, Ballantyne AP, Ravet JL, Goldman CR (2006) Daphnia fatty acid composition reflects that of their diet. Limnol Oceanogr 51:2428-2437

Brett MT, Muller-Navarra DC, Persson J (2009) Crustacean zooplankton fatty acid composition. In: Arts MT, Kainz MJ, Brett MT (ed) Lipids in aquatic ecosystems. Springer, New York, pp 115-146

Burlakova L, Karatayev A, Padilla DK (2000) The impact of Dreissena polymorpha (Pallas) invasion on unionid bivalves. Int Rev Hydrobiol 85:529-541

Caraco NF, Cole JJ, Raymond PA, Strayer DL, Pace ML, Findlay SEG, Fischer DT (1997) Zebra mussel invasion in a large, turbid river: phytoplankton response to increased grazing. Ecology 78:588-602

Caramujo M-J, Boschker HTS, Admiraal W (2008) Fatty acid profiles of algae mark the development and composition of harpacticoid copepods. Freshw Biol 53:77-90

Carrido JL, Medina I (2002) Identification of minor fatty acids in mussels (Mytilus galloprovincialis) by GC-MS of their 2-alkenyl-4,4-dimethyloxazoline derivatives. Anal Chim Acta 465:409-416

Castell JD, Kennedy EJ, Robinson SMC, Parsons GJ, Blair TJ, Gonzalez-Duran E (2004) Effect of dietary lipids on fatty acid composition and metabolism in juvenile green sea urchins (Strongylocentrotus droebachiensis). Aquaculture 242:417-435

Christian AD, Smith BN, Berg DJ, Smoot JC, Findlay RH (2004) Trophic position and potential food sources of 2 species of unionid bivalves (Mollusca: Unionidae) in 2 small Ohio streams. I N Am Benthol Soc 23:101-113

Christie WW (2003) Lipid analysis - isolation, separation, identification and structural analysis of lipids. Oily Press, Bridgwater, England

Cole JJ, Solomon CT (2012) Terrestrial support of zebra mussels and Hudson River food web: a multi-isotope, Bayesian analysis. Limnol Oceanogr 57:1802-1815

De Troch M, Boeckx P, Cnudde C, Van Gansbeke D, Vanreusel A, Vincx M, Caramujo MJ (2012) Bioconversion of fatty acids at the basis of marine food webs: insights from a compound-specific stable isotope analysis. Mar Ecol Progr Ser 465:53-67

Desvilettes C, Bourdier G, Amblard C, Barth B (1997) Use of fatty acids for the assessment of zooplankton grazing on bacteria, protozoans and microalgae. Freshw Biol 38:629-637

Dijkman NA, Kromkamp JC (2006) Phospholipid-derived fatty acids as chemotaxonomic markers for phytoplankton: application for inferring phytoplankton composition. Mar Ecol Progr Ser 324:113-125

Dionisio Pires LM, Jonker RR, Van Donk E, Laanbroek HJ (2004) Selective grazing by adults and larvae of the zebra mussel (Dreissena polymorpha): application of flow cytometry to natural seston. Freshw Biol 49:116-126

Gladyshev MI, Sushchik NN, Anishchenko OV, Makhutova ON, Kolmakov VI, Kalachova GS, Kolmakova AA, Dubovskaya OP (2011) Efficiency of transfer of essential polyunsaturated fatty acids versus organic carbon from producers to consumers in a eutrophic reservoir. Oecologia 165:521-531

Green CT, Scow KM (2000) Analysis of phospholipid fatty acids (PLFA) to characterize microbial communities in aquifers. Hydrogeol f 8:126-141

Guevara M, Bastardo L, Cortez R, Arredondo-Vega B, Romero L, Gomez P (2011) Rhodomonas salina (Cryptophyta) pastes as feed for Brachionus plicatilis (Rotifera). Rev Biol Trop 59:1503-1515

Gugger M, Lyra C, Suominen I, Tsitko I, Humbert J-F, Salkinoja-Salonen MS, Sivonen K (2002) Cellular fatty acids as chemotaxonomic markers of the genera Anabaena, Aphanizomenon, Microcystis, Nostoc and Planktothrix (cyanobacteria). Int J Syst Evol Microbiol 52:1007-1015

Hagen W, Kattner G, Graeve M (1993) Calanoides acutus and Calanus propinquus, Antarctic copepods with different lipid storage modes via wax esters or triacylglycerols. Mar Ecol Progr Ser 97:135-142

Hama T (1999) Fatty acid composition of particulate matter and photosynthetic products in subarctic and subtropical Pacific. J Plankt Res 21:1355-1372

Irazù CE, Pollero RJ, Brenner RR (1984) Occurrence of a 22:2 nonmethylene interrupted dienoic fatty acid and its seasonal distribution among lipids and tissues of the freshwater bivalve Diplodon delodontus from an isolated environment. Lipids 19:649-655

Jokela A, Ricciardi A (2008) Predicting zebra mussel fouling on native mussels from physicochemical variables. Freshw Biol 53:1845-1856

Karatayev AY, Burlakova LE, Padilla DK (1997) The effects of Dreissena polymorpha (Pallas) invasion on aquatic communities in Eastern Europe. J Shellfish Res 16:187-203 
Karatayev AY, Burlakova LE, Padilla DK (2002) Impacts of zebra mussels on aquatic communities and their role as ecosystem engineers. In: Leppäkoski E, Gollasch S, Olenin S (ed) Invasive aquatic species of Europe - distribution, impacts and management. Kluwer, Dordrecht, pp 433-446

Kattner G, Hagen W, Lee RF, Campbell R, Deibel D, Falk-Petersen S, Graeve M, Hansen BW, Hirche HJ, Jónasdóttir SH, Madsen ML, Mayzaud P, MüllerNavarra D, Nichols PD, Paffenhöfer G-A, Pond D, Saito H, Stübing D, Virtue P (2007) Perspectives on marine zooplankton lipids. Can J Fish Aquat Sci 64:1628-1639

Kawashima H, Ohnishi M (2004) Lipids identification of minor fatty acids and various nonmethylene-interrupted diene isomers in mantle, muscle, and viscera of the marine bivalve Megangulus zyonoensis. Lipids 39:265-271

Kelly JR, Scheibling RE (2012) Fatty acids as dietary tracers in benthic food webs. Mar Ecol Progr Ser 446:1-22

Kharchenko TA, Zorina-Sakharova EE (2002) The ecological consortia of bivalve mollusks in littoral zones of a flatland reservoir, as a structural and functional community of hydrobionts. Hydrobiol J 38:3-14

Kharlamenko VI, Kiyashko SI, Rodkina SA, Svetashev VI (2011) The composition of fatty acids and stable isotopes in the detritophage Acila insignis (Gould, 1861) (Bivalvia: Nuculidae): searching for markers of a microbial food web. Russ J Mar Biol 37:201-208

Kraffe E, Grall J, Le Duff M, Soudant P, Marty Y (2008) A striking parallel between cardiolipin fatty acid composition and phylogenetic belonging in marine bivalves: a possible adaptative evolution? Lipids 43:961-970

Lau DCP, Vrede T, Pickova J, Goedkoop W (2012) Fatty acid composition of consumers in boreal lakes - variation across species, space and time. Freshw Biol 57:24-38

Legendre P, Legendre L (2012) Numerical ecology. Elsevier Science, Amsterdam

Makhutova ON, Sushchik NN, Gladyshev MI, Ageev AV, Pryanichnikova EG, Kalachova GS (2011) Is the fatty acid composition of freshwater zoobenthic invertebrates controlled by phylogenetic or trophic factors? Lipids 46:709-721

Makhutova ON, Pryanichnikova EG, Lebedeva IM (2012) Comparison of nutrition range in Dreissena polymorpha and Dreissena bugensis mussels by biochemical markers. Contemp Probl Ecol 5:459-469

Mansour MP, Holdsworth DG, Forbes SE, Macleod CK, Volkman JK (2005) High contents of 24:6(n-3) and 20:1(n-13) fatty acids in the brittle star Amphiura elandiformis from Tasmanian coastal sediments. Biochem Syst Ecol 33:659-674

Mezek T, Sverko E, Rudy MD, Zaruk D, Capretta A, Hebert CF, Fisk AT, McGoldrick DJ, Newton TJ, Sutton TM, Koops MA, Muir AM, Johnson TB, Ebener MP, Arts MT (2011) Polymethylene-interrupted fatty acids: biomarkers for native and exotic mussels in the Laurentian Great Lakes. J Great Lakes Res 37:289-297

Molloy DP, Karatayev AY, Burlakova LE, Kurandina DP, Laruelle F (1997) Natural enemies of zebra mussels: predators, parasites and ecological competitors. Rev Fish Sci 5:27-97

Naddafi R, Pettersson K, Eklöv P (2007) The effect of seasonal variation in selective feeding by zebra mussels (Dreissena polymorpha) on phytoplankton community composition. Freshw Biol 52:823-842

Napolitano GE (1999) Fatty acids as trophic and chemical markers in freshwater ecosystems. In: Arts MT, Wainman BC (ed) Lipids in freshwater ecosystems. Springer-Verlag, New York, pp 21-44

Nichols SJ, Garling D (2000) Food-web dynamics and trophic-level interactions in a multispecies community of freshwater unionids. Can J Zool 78:871-882

Pace ML, Findlay SEG, Fischer D (1998) Effects of an invasive bivalve on the zooplankton community of the Hudson River. Freshw Biol 39:103-116

Petkov G, Garcia G (2007) Which are fatty acids of the green alga Chlorella? Biochem Syst Ecol 35:281-285

Pirini M, Manuzzi MP, Pagliarani A, Trombetti F, Borgatti AR, Ventrella V (2007) Changes in fatty acid composition of Mytilus galloprovincialis ( $\mathrm{Lmk}$ ) fed on microalgal and wheat germ diets. CompBiochem Physiol B 147:616-626

Prato E, Danieli A, Maffia M, Biandolino F (2012) Lipid contents and fatty acid compositions of Idotea baltica and Sphaeroma serratum (Crustacea: Isopoda) as indicators of food sources. Zool Stud 51:38-50

Ricciardi A, Whoriskey FG, Rasmussen JB (1995) Predicting the intensity and impact of Dreissena infestation on native unionid bivalves from Dreissena field density. Can J Fish Aquat Sci 52:1449-1461

Saito H, Hashimoto J (2010) Characteristics of the fatty acid composition of a deep-sea vent gastropod, Ifremeria nautilei. Lipids 45:537-548

Saito H, Osako K (2007) Confirmation of a new food chain utilizing geothermal energy: unusual fatty acids of a deep-sea bivalve, Calyptogena phaseoliformis. Limnol Oceanogr 52:1910-1918
Saliot A, Mejanelle L, Scribe P, Fillaux J, Pepe C, Jabaud A, Dagaut J (2001) Particulate organic carbon, sterols, fatty acids and pigments in the Amazon River system. Biogeochemistry 53:79-103

Shin KH, Hama T, Yoshie N, Noriki S, Tsunogai S (2000) Dynamics of fatty acids in newly biosynthesized phytoplankton cells and seston during a spring bloom off the west coast of Hokkaido Island. Japan Mar Chem 70:243-256

Shorland FB (1963) The distribution of fatty acids in plant lipids. In: Swain T (ed) Chemical plant taxonomy. Academy Press, New York, pp 253-311

Sousa R, Pilotto F, Aldridge DC (2011) Fouling of European freshwater bivalves (Unionidae) by the invasive zebra mussel (Dreissena polymorpha). Freshw Biol $56: 867-876$

Starodubtsev VM, Bogdanets VA (2012) Dynamics of hydromorphic landscapes in the upper parts of Dnieper reservoirs. Water Resour 39:180-183

Strayer DL, Hattala K, Kahnle A (2004) Effects of an invasive bivalve (Dreissena polymorpha) on fish populations in the Hudson River estuary. Can J Fish Aquat Sci 61:924-941

Strayer DL, Pace ML, Caraco NF, Cole JJ, Findlay SEG (2008) Hydrology and grazing jointly control a large-river food web. Ecology 89:12-18

Thorp JH, Casper AF (2002) Potential effects on zooplankton from species shifts in planktivorous mussels: a field experiment in the St. Lawrence River. Freshw Biol 47:107-119

Vanderploeg HA, Johengen TH, Liebig JR (2009) Feedback between zebra mussel selective feeding and algal composition affects mussel condition: did the regime changer pay a price for its success? Freshw Biol 54:47-63

Vaughn CC, Nichols SJ, Spooner DE (2008) Community and foodweb ecology of freshwater mussels. J N Am Benth Soc 27:409-423

Viso AC, Marty JC (1993) Fatty acids from 28 marine microalgae. Phytochemistry 34:1521-1533

Vuorio K, Tarvainen M, Sarvala J (2007) Unionid mussels as stable isotope baseline indicators for long-lived secondary consumers in pelagic food web comparisons. Fund Appl Limnol 169:237-245

Zhukova N (2007) Lipid classes and fatty acid composition of the tropical nudibranch mollusks Chromodoris sp. and Phyllidia coelestis. Lipids 42:1169-1175

\section{doi:10.1186/1810-522X-52-56}

Cite this article as: Makhutova et al:: Feeding spectra of bivalve mollusks Unio and Dreissena from Kanevskoe Reservoir, Ukraine: are they food competitors or not? Zoological Studies 2013 52:56.

\section{Submit your manuscript to a SpringerOpen ${ }^{\circ}$ journal and benefit from:}

- Convenient online submission

Rigorous peer review

- Immediate publication on acceptance

- Open access: articles freely available online

- High visibility within the field

- Retaining the copyright to your article

Submit your next manuscript at $\gg$ springeropen.com 